\title{
A survey on relationship between capital structure, free cash flow and diversification and firm performance of listed companies in Tehran Stock Exchange
}

\author{
Mohammad Khodaei Valahzaghard ${ }^{\mathrm{a}^{*}}$ and Maryam Borzabadi Farahani ${ }^{\mathrm{b}}$
}

\begin{abstract}
${ }^{a}$ Assist. Prof. \& Faculty Member, Department of Accounting, School of Management and Human Sciences, Tehran North Branch, Islamic Azad University (IAU), Tehran, Iran

${ }^{b}$ M.Sc. Student, Department of Accounting, School of Management and Human Sciences, Tehran North Branch, Islamic Azad University (IAU), Tehran, Iran

CHRON I C LE

Article history:

Received May 4, 2014

Accepted 24 September 2014

Available online

September 272014

Capital structure

Free cash flow

Diversification

Firm performance

\section{A B S T R A C T}

This paper presents an empirical investigation to study the effects of free cash flow, share diversification and capital structure on Tobin-Q in selected firms on Tehran Stock Exchange. The population of the survey includes 520 firms listed on this exchange until year 2012 and the survey uses a sample of 105 firms, randomly. The study uses the models originally developed by Palepu (1985) [Palepu, K. (1985). Diversification strategy, profit performance and the entropy measure. Strategic Management Journal, 6(3), 239-255.] to measure the effects of different factors on Tobin Q. The study has indicated that while capital structure and free cash flow influence positively on Tobin Q, diversification has maintained a negative and meaningful relationship with Tobin Q.
\end{abstract}

\section{Introduction}

Capital structure is considered as the most important parameter affecting the valuation of corporates (Booth, et al., 2001; De Jong, 2002; Hasan \& Butt, 2009; Fairfield et al., 2003). Changing and changeable environment, the credit rating companies is partly dependent on their capital structure (La Rocca et al., 2009). Fluid variables and factors affecting the capital structure can be described in terms of profitability and efficiency in target coverage, representation theory and the theory of hierarchy affect compliance (Tang \& Jang, 2010; Dechow et al., 2008). Variability of stock, a uniform change in stock ownership is essential and influential factor in predicting future cash flows (Doukas \& Kan, 2004). According to sources of finance, companies have different return and risk (Campa \& Kedia, 2002). However, the name of the area of operations, profitability, growth opportunities, size and type of activity would be detrimental to their diverse financial needs (Gill et al., 2008). Financial performance will be somehow affected by the financial leverage ratio changes (Menéndez-Alonso, 2003). Other factors such as take over (Zhao et al., 2009), corporate governance (Wen et al., 2002, Scott Jr, 1972; Erickson \& Wang, 1999), capital investment (Titman et al., 1998, 2004; Theis \& Casey, 1999), intellectual capital (Tan et al. 2007; Brush et al., 2000), corporate

*Corresponding author. Tel: +98-912-3443139

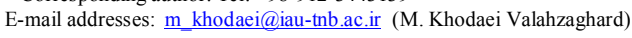

C) 2014 Growing Science Ltd. All rights reserved.

doi: $10.5267 /$ j.ms 1.2014.9.018 
ownership (Kapopoulos \& Lazaretou, 2007; DeFond et al., 2012), information asymmetry (Coller \& Yohn, 1997; Basu, 1997; Dichev \& Tang, 2009) also influence on financial performance.

\section{The proposed study}

This paper presents an empirical investigation to study the relationship between capital structure, free cash flow and diversification and Tobin's Q of listed companies in Tehran Stock Exchange. The population of the survey includes 520 firms listed on this exchange until year 2012 and the survey uses a sample of 105 firms, randomly. The study uses the model originally developed by Palepu (1985) as follows,

$$
\begin{aligned}
& \operatorname{Ln}(\text { Tobinsq })_{i, t}=\alpha_{0}+\beta_{1} \operatorname{Ln}(T D L)_{i, t}+\beta_{2} \text { Cashflow }_{l, t}+\beta_{3} \operatorname{Ln}\left(\text { Sales_GR }_{i, t}+\beta_{4} \text { dummy_Dividend }_{t, t}\right. \\
& +\beta_{5} \operatorname{Ln}\left(A d_{-} E X\right)_{t}+\beta_{6} R E R_{i, t}+\beta_{7} P P N E_{i, t}+\beta_{8} Q R_{i, t}+\varepsilon_{i, t} \\
& \operatorname{Ln}(\text { Tobin, sq })_{i, t}=\alpha_{0}+\beta_{1} F_{C F_{i, t}}+\beta_{2} \text { Cashflow }_{i, t}+\beta_{3} \operatorname{Ln}\left(\text { Sales_GR }_{i, t}+\beta_{4} \text { dummy_Dividend }_{i, t}\right. \\
& +\beta_{5} \operatorname{Ln}\left(A d_{-} E X\right)_{t}+\beta_{6} R E R_{i, t}+\beta_{7} P P N E_{i, t}+\beta_{8} Q R_{i, t}+\varepsilon_{i, t} \\
& \operatorname{Ln}(\text { Tobinsq })_{i, t}=\alpha_{0}+\beta_{1} D R_{i, t} * D U_{i, t}+\beta_{2} \text { Cashflow }_{, t}+\beta_{3} \operatorname{Ln}(\text { Sales_GR })_{i, t}+\beta_{4} \text { dummy_Dividend }, t \\
& +\beta_{5} \operatorname{Ln}\left(A d_{-} E X\right)_{t}+\beta_{6} R E R_{i, t}+\beta_{7} P P N E_{i, t}+\beta_{8} Q R_{i, t}+\varepsilon_{i, t}
\end{aligned}
$$

where TDL, FCF, Cashflow, Sales_GR, Ad_EX represent total degree of leverage, free cash flow, cash flow, sales growth, Capital expenditures, respectively. In addition, $R E R, P P N E Q R$, and $D R$ represent ratio of retained earnings to assets, fixed assets to total assets ratio, quick ratio and diversity ratio, respectively. Moreover, dummy_Dividend is a dummy variable, which is one if a firm pays dividend and zero, otherwise and finally, Tobin's Q is considered as dependent variable in all models. Models (1-3) are considered for testing three hypotheses as follows,

1. There is a meaningful relationship between Tobin's $Q$ and total degree of leverage.

2. There is a meaningful relationship between Tobin's Q and free cash flow.

3. There is a meaningful relationship between Tobin's Q and share diversity.

Table 1 demonstrates the summary of some basic statistics. The preliminary results of Table 1 indicate that all data are normally distributed. However, the implementation of Kolmogorov-Smirnov test on Tobin Q yields K-S $=4.073$ with Sig. $=0.000$, which means the dependent variable is not normally distributed and we need to use Johnson Transformation to normalize the data, which yields $\mathrm{K}-\mathrm{S}=0.515$ with Sig. $=0.954$. Therefore, we may now use regression analysis to examine three hypotheses of the survey. Finally, we have investigation correlations among different pairs of independent variables. In our survey, we have not found any significant relationship.

Table 1

The summary of some basic statistics

\begin{tabular}{cccccccc}
\hline Variable & $\mathrm{N}$ & Mean & Standard deviation & Min & Max & Skewness & Kurtosis \\
\hline Tobin Q & 630 & 0.3569 & 0.6143 & -1.8947 & 1.5664 & -0.947 & -0.023 \\
TDL & 630 & 1.4764 & 0.4815 & 1.002 & 3.8758 & 1.319 & 1.368 \\
Free Cash Flow & 630 & 0.2338 & 0.1738 & -1.0159 & 0.4402 & -1.177 & 3.749 \\
DR & 630 & 0.53 & 0.4242 & -0.7967 & 0.8357 & -2.394 & 3.962 \\
Cash Flow & 630 & 0.3332 & 0.8817 & -3.6794 & 3.4254 & 0.935 & 3.042 \\
Ln(Sales_Growth) & 630 & 1.1165 & 0.0461 & 0.9845 & 1.265 & 0.384 & 0.283 \\
Dummay Dividend & 630 & 0.9342 & 0.2468 & 0 & 1 & -3.535 & 10.528 \\
Ad-EX & 630 & 0.482 & 0.8676 & -4.1777 & 3.4028 & -0.49 & 3.544 \\
RER & 630 & 0.1195 & 0.5448 & -2.5185 & 11.2685 & 14.069 & 282.391 \\
PPNE & 630 & 0.25 & 0.186 & 0.0008 & 0.8786 & 1.035 & 0.679 \\
QR & 630 & 1.3528 & 0.4895 & 0.2452 & 2.9964 & 0.778 & 0.799 \\
\hline
\end{tabular}




\section{The results}

In this section, we present details of the implementation of regression analysis on Eq. (1) to Eq. (3).

\subsection{The relationship between degree of leverage and Tobin $Q$}

The first hypothesis of this survey investigates the relationship between degree of leverage and Tobin Q. Table 2 demonstrates the results of Chaw and Huasman. Based on the results of Table 2 we may use Panel data with fixed effect. Table 3 shows details of other necessary statistics.

\section{Table 2}

The summary of Chaw and Huasman tests

\begin{tabular}{lccccc}
\hline Test & Number & Statistics & Statistics value & Degree of freedom & Sig. \\
\hline Chaw & 630 & $\mathrm{~F}$ & 3.6445 & $(104,515)$ & 0.0000 \\
Hausman & 630 & Chi-Square & 25.4633 & 8 & 0.0013 \\
\hline
\end{tabular}

\section{Table 3}

The results of some statistics

\begin{tabular}{ccccccc}
\hline \multicolumn{2}{c}{ Jarque-Bera } & \multicolumn{2}{c}{ Breusch-Pagan } & \multicolumn{2}{c}{ Durbin-Watson } & \multicolumn{2}{c}{ Ramsey } \\
\hline Chi-Square & P-value & F & P-value & D & F & P-value \\
\hline 1.9137 & 0.8721 & 2.6604 & 0.0071 & 2.10 & 2.8608 & 0.0580 \\
\hline
\end{tabular}

As we can observe from the results of Table 3, all statistics are within the acceptable level and we may examine the first hypothesis based on the regression technique as follows,

\begin{tabular}{|c|c|c|c|c|c|c|c|c|}
\hline t-value & $-1.1486 \quad 0.2576$ & 0.5986 & 0.7530 & 2.0886 & -1.2141 & 0.2118 & -2.5096 & 0.2747 \\
\hline P-value & 0.25120 .0168 & 0.5497 & 0.4518 & 0.0372 & 0.2252 & 0.8323 & 0.0124 & 0.7837 \\
\hline $\mathrm{R}^{2}=0.4406$ & F-value $=3.6221$ & & & & & & & \\
\hline
\end{tabular}

As we can observe from the results of generalized regression analysis (GLS), there is a meaningful relationship between TDL and Ln(Tobin's Q), $(\beta=0.0160 \mathrm{t}$-value $=0.2576$, P-value $=0.0168)$. RSquare is equal to 0.4406 , which means the independent variables could approximately describe $44 \%$ of the changes on dependent variable. F-value is equal to 3.6221 with p-value $=0.000$, which means there is a linear relationship between independent variables and dependent variable. These results lead us to confirm the first hypothesis of the survey.

\subsection{The relationship between free cash flow and Tobin $Q$}

The second hypothesis of this survey studies the relationship between cash flow and Tobin Q. Table 4 shows the results of Chaw and Huasman. Based on the results of Table 4 we may use Panel data with fixed effect. Table 5 shows details of other necessary statistics.

\section{Table 4}

The summary of Chaw and Huasman tests

\begin{tabular}{lccccc}
\hline Test & Number & Statistics & Statistics value & Degree of freedom & Sig. \\
\hline Chaw & 630 & F & 3.5280 & $(104,515)$ & 0.0000 \\
Hausman & 630 & Chi-Square & 42.5518 & 8 & 0.0000 \\
\hline
\end{tabular}

\section{Table 5}

The results of some statistics

\begin{tabular}{ccccccc}
\hline \multicolumn{2}{c}{ Jarque-Bera } & \multicolumn{2}{c}{ Breusch-Pagan } & Durbin-Watson & \multicolumn{2}{c}{ Ramsey } \\
\hline Chi-Square & P-value & F & P-value & D & F & P-value \\
\hline 1.8331 & 0.7965 & 2.1986 & 0.0260 & 2.15 & 0.2770 & 0.7581 \\
\hline
\end{tabular}


As we can observe from the results of Table 5, all statistics are within the acceptable level and we may examine the second hypothesis based on the regression technique as follows,

\begin{tabular}{|c|c|c|c|c|c|c|c|c|c|}
\hline t-value & -1.5835 & 2.1031 & 1.1963 & 1.1906 & 2.3732 & -0.6544 & 0.2208 & -2.3745 & 1.0165 \\
\hline $\mathrm{P}$-value & 0.1139 & 0.0359 & 0.2321 & 0.0180 & 0.0180 & 0.5131 & 0.8253 & 0.0179 & 0.3100 \\
\hline
\end{tabular}

$\mathrm{R}^{2}=0.5597 \quad$ F-value $=3.9129 \quad$ Sig. 0.0000

As we can observe from the results of generalized regression analysis (GLS), there is meaningful relationship between FCF and $\mathrm{Ln}$ (Tobin's Q), $(\beta=0.0909$ t-value $=2.1031$, P-value $=0.0359)$. RSquare is equal to 0.5597 , which means the independent variables could approximately describe $56 \%$ of the changes on dependent variable. F-value is equal to 3.9129 with $p$-value $=0.000$, which means there is a linear relationship between independent variables and dependent variable. These results lead us to confirm the second hypothesis of the survey and conclude that there was a positive and meaningful relationship between free cash flow and Tobin Q.

\subsection{The relationship between share diversity and Tobin $Q$}

The third hypothesis of this survey studies the relationship between share diversity and Tobin Q. Table 6 presents the results of Chaw and Huasman. Based on the results of Table 6 we may use Panel data with fixed effect. Table 7 shows details of other necessary statistics.

Table 6

The summary of Chaw and Huasman tests

\begin{tabular}{lccccc}
\hline Test & Number & Statistics & Statistics value & Degree of freedom & Sig. \\
\hline Chaw & 630 & $\mathrm{~F}$ & 9.3843 & $(104,515)$ & 0.0000 \\
Hausman & 630 & Chi-Square & 28.7292 & 8 & 0.0004 \\
\hline
\end{tabular}

Table 7

The results of some statistics

\begin{tabular}{ccccccc}
\hline \multicolumn{2}{c}{ Jarque-Bera } & \multicolumn{2}{c}{ Breusch-Pagan } & Durbin-Watson & \multicolumn{2}{c}{ Ramsey } \\
\hline Chi-Square & P-value & F & P-value & D & F & P-value \\
\hline 1.6565 & 0.5898 & 2.1489 & 0.0297 & 1.79 & 0.2988 & 0.7417 \\
\hline
\end{tabular}

As we can observe from the results of Table 7, all statistics are within the acceptable level and we may examine the second hypothesis based on the regression technique as follows,

\begin{tabular}{|c|c|c|c|c|c|c|c|c|c|}
\hline t-value & 1.9128 & -3.7679 & 0.0673 & 0.6601 & 1.1491 & -10.9237 & -1.2558 & 2.0215 & -0.3162 \\
\hline P-value & 0.0568 & 0.0002 & 0.9464 & 0.5094 & 0.2510 & 0.0000 & 0.2097 & 00437 & 0.7519 \\
\hline
\end{tabular}

$\mathrm{R}^{2}=0.7204 \quad$ F-value $=11.8525 \quad$ Sig. 0.0000

As we can observe from the results of generalized regression analysis (GLS), there is a meaningful relationship between DR and Ln(Tobin's Q), $(\beta=0.0909$ t-value $=2.1031$, P-value $=0.0359)$. RSquare is equal to 0.7204 , which means the independent variables could approximately describe $56 \%$ of the changes on dependent variable. F-value is equal to 11.8525 with $p$-value $=0.000$, which means there is a linear relationship between independent variables and dependent variable. These results lead us to confirm the last hypothesis of the survey and conclude that there was a negative and meaningful relationship between share diversity and Tobin Q.

\section{Conclusion}

This paper presents an empirical investigation to study the effects of free cash flow, share diversification and capital structure on Tobin-Q in selected firms on Tehran Stock Exchange. The population of the survey includes 520 firms listed on this exchange until year 2012. The study has indicated that capital structure and free cash flow influenced positively on Tobin Q. In addition, 
diversification maintained a negative and meaningful relationship with Tobin Q. Nawaz et al. (2011) reported a positive and meaningful relationship between capital structure and Tobin Q but the results are not consistent with findings of Arslan and Karan (2007) and Ebaid et al. (2009). In addition, in terms of firm diversification, the results of our study are somewhat consistent with findings of Anderson et al. (1998), Menéndez-Alonso (2003), Rajan et al., 2000, La Rocca et al. (2009) and Chkir and Cosset (2001).

\section{Acknowledgement}

The authors would like to thank the anonymous referees for constructive comments on earlier version of this paper.

\section{References}

Anderson, R. C., Bizjak, J. M., Lemmon, M. L., \& Bates, T. W. (1998). Corporate governance and firm diversification. Available at SSRN 121013.

Arslan, Ö., \& Karan, M. B. (2007). Does Free cash flow anomaly exist in an Emerging Market? Evidence from the Istanbul Stock Exchange. International Research Journal of Finance and Economics, 11, 163-171.

Basu, S. (1997). The conservatism principle and the asymmetric timeliness of earnings. Journal of accounting and economics, 24(1), 3-37.

Booth, L., Aivazian, V., Demirguc-Kunt, A., \& Maksimovic, V. (2001). Capital structures in developing countries. The Journal of Finance, 56(1), 87-130.

Brush, T. H., Bromiley, P., \& Hendrickx, M. (2000). The free cash flow hypothesis for sales growth and firm performance. Strategic Management Journal, 21(4), 455-472.

Campa, J. M., \& Kedia, S. (2002). Explaining the diversification discount. The Journal of Finance, 57(4), 1731-1762.

Chen, F., Lam, K., Smieliauskas, W., \& Ye, M. (2010). Fair value measurements and auditor versus management conservatism: Evidence from the banking industry. Working paper, University of Toronto.

Chi, W., Liu, C., \& Wang, T. (2009). What affects accounting conservatism: A corporate governance perspective. Journal of contemporary accounting \& economics, 5(1), 47-59.

Chkir, I. E., \& Cosset, J. C. (2001). Diversification strategy and capital structure of multinational corporations. Journal of Multinational Financial Management,11(1), 17-37.

Coller, M., \& Yohn, T. L. (1997). Management forecasts and information asymmetry: An examination of bid-ask spreads. Journal of Accounting Research, 35, 181-191.

De Jong, A. (2002). The disciplining role of leverage in Dutch firms. European Finance Review, 6(1), 31-62.

Dechow, P. M., Richardson, S. A., \& Sloan, R. G. (2008). The persistence and pricing of the cash component of earnings. Journal of Accounting Research,46(3), 537-566.

DeFond, M. L., Lim, C. Y., \& Zang, Y. (2012). Do Auditors Value Client Conservatism?. University of Southern California, Singapore Management University.

Dichev, I. D., \& Tang, V. W. (2009). Earnings volatility and earnings predictability. Journal of accounting and Economics, 47(1), 160-181.

Doukas, J. A., \& Kan, O. B. (2004). Excess cash flows and diversification discount. Financial Management, 33, 71-88.

Ebaid, I. E. S. (2009). The impact of capital-structure choice on firm performance: empirical evidence from Egypt. Journal of Risk Finance, The,10(5), 477-487.

Erickson, M., \& Wang, S. W. (1999). Earnings management by acquiring firms in stock for stock mergers. Journal of Accounting and Economics, 27(2), 149-176.

Fairfield, P. M., Whisenant, J. S., \& Yohn, T. L. (2003). Accrued earnings and growth: Implications for future profitability and market mispricing. The Accounting Review, 78(1), 353-371. 
Gill, A., Biger, N., \& Bhutani, S. (2008). Corporate performance and the chief executive officer's compensation in the service industry. Open Business Journal, 1, 53-57.

Greene, W. H. (2003). Econometric analysis. Pearson Education India.

Hasan, A., \& Butt, S. A. (2009). Impact of ownership structure and corporate governance on capital structure of Pakistani listed companies. International Journal of Business and Management, 4(2), P50.

Jang, S. S., \& Park, K. (2011). Inter-relationship between firm growth and profitability. International Journal of Hospitality Management, 30(4), 1027-1035.

Jensen, M. C. (1986). Agency costs of free cash flow, corporate finance, and takeovers. The American economic review, 76, 323-329.

Kapopoulos, P., \& Lazaretou, S. (2007). Corporate ownership structure and firm performance: evidence from Greek firms. Corporate Governance: An International Review, 15(2), 144-158.

La Rocca, M., La Rocca, T., Gerace, D., \& Smark, C. (2009). Effect of diversification on capital structure. Accounting \& Finance, 49(4), 799-826.

Menéndez-Alonso, E. J. (2003). Does diversification strategy matter in explaining capital structure? Some evidence from Spain. Applied Financial Economics, 13(6), 427-430.

Nawaz, A., Ali, R., \& Naseem, M. A. (2011). Relationship between Capital Structure and Firms Performance: A Case of Textile Sector in Pakistan. Global Business and Management Research: An International Journal, 3, 270-274.

Palepu, K. (1985). Diversification strategy, profit performance and the entropy measure. Strategic management journal, 6(3), 239-255.

Rajan, R., Servaes, H., \& Zingales, L. (2000). The cost of diversity: The diversification discount and inefficient investment. The Journal of Finance, 55(1), 35-80.

Scott Jr, D. F. (1972). Evidence on the importance of financial structure. Financial Management, 4, 45-50.

Tan, H. P., Plowman, D., \& Hancock, P. (2007). Intellectual capital and financial returns of companies. Journal of Intellectual capital, 8(1), 76-95.

Tang, C. H. H., \& Jang, S. S. (2010). Does international diversification discount exist in the hotel industry?. Journal of Hospitality \& Tourism Research, 32(4), 225-246.

Theis, J., \& Casey, M. (1999). An empirical investigation of agency relationships and capital structure of property management firms in the UK. Journal of Property Investment \& Finance, 17(1), 27-34.

Titman, S., \& Wessels, R. (1988). The determinants of capital structure choice. The Journal of finance, 43(1), 1-19.

Titman, S., Wei, K. C., \& Xie, F. (2004). Capital investments and stock returns. Journal of Financial and Quantitative Analysis, 39(04), 677-700.

Wen, Y., Rwegasira, K., \& Bilderbeek, J. (2002). Corporate governance and capital structure decisions of the Chinese listed firms. Corporate Governance: An International Review, 10(2), $75-$ 83.

Zhao, Y., Chen, K. H., \& Yao, L. J. (2009). Effects of takeover protection on earnings overstatements: evidence from restating firms. Review of Quantitative Finance and Accounting, 33(4), 347-369. 